\title{
SPIRITUAL TEACHING DALAM PEMBELAJARAN IPA DI MADRASAH
}

\author{
Laely Mahmudah \\ MTs Negeri Sumbang, Banyumas, Jawa Tengah, Indonesia. \\ laely_mahmudah@yahoo.co.id
}

\begin{abstract}
Abstrak
Tujuan pendidikan nasional harus diwujudkan melalui serangkaian proses pembelajaran. Salah satu cara untuk mewujudkannya adalah dengan spiritual teaching. Spiritual teaching yaitu mengajar dan membimbing peserta didik dengan menanamkan nilai atau semangat religius diintegrasikan dalam konsep pengetahuan dan keterampilan sesuai dengan tujuan pembelajaran. Hakikat pembelajaran IPA meliputi empat unsur utama, yaitu sikap, proses, produk, dan aplikasi. Spiritual teaching dalam pembelajaran IPA di madrasah dapat diimplementasikan melalui beberapa cara, diantaranya melalui: 1) Pembelajaran Reflektif, 2) Pembelajaran Kontesktual (CTL), 3) Spritual Educational Game (SEG), dan 4) Pembelajaran Outdoor. Guru dapat memilih metode pembelajaran yang akan diterapkan disesuaikan dengan materi yang disampaikan. Apabila guru menerapkan spiritual teaching dalam pembelajaran IPA di madrasah, diharapkan dapat mewujudkan peserta didik yang cerdas secara komprehensif, cerdas intelektual, cerdas spiritual, dan cerdas sosial/emosional.
\end{abstract}

Kata Kunci: spiritual teaching, IPA, madrasah. 


\section{Abstract}

SPRITUAL TEACHING IN SCIENCE LEARNING IN MADRASAH. The purpose of national education must be realized in a series of learning process. One of the ways to realize it is by applying the spiritual teaching. Spiritual teaching is teaching and guiding the learners by instilling values and religious spirit which is integrated in knowledge and skill concept in accordance with the learning purposes. The essence of science learning includes four main elements. They are attitude, process, product, and application. Spiritual teaching in science learning in madrasah can be implemented in some ways, some of them are: 1) reflective learning, 2) contextual learning (CTL), 3) spiritual educational game (SEG), and 4) outdoor learning. The teacher is able to choose the learning method that will be applied. It is associated with the material that will be delivered. When the teacher applies the spiritual teaching in science learning in madrasah, it is hoped that the students will be smart comprehensively, intellectually, spiritually, and emotionally/socially.

Keywords: spiritual teaching, science, madrasah.

\section{A. Pendahuluan}

Tujuan pendidikan nasional dalam Undang-undang Nomor 20 Tahun 2003 adalah untuk berkembangnya potensi peserta didik agar menjadi manusia yang beriman dan bertakwa kepada Tuhan Yang Maha Esa, berakhlak mulia, sehat, berilmu, cakap, kreatif, mandiri, dan menjadi warga negara yang demokratis serta bertanggung jawab. Sejalan dengan arahan undangundang tersebut, telah ditetapkan visi pendidikan tahun 2025 yaitu menciptakan insan Indonesia yang cerdas dan kompetitif. Cerdas yang dimaksud adalah cerdas komprehensif, yaitu cerdas spiritual dan cerdas sosial/emosional dalam ranah sikap, cerdas intelektual dalam ranah pengetahuan, serta cerdas kinestetis dalam ranah keterampilan.

Untuk mewujudkan tujuan pendidikan nasional, dirumuskan standar kompetensi lulusan yaitu kualifikasi kemampuan lulusan yang mencakup sikap, pengetahuan, dan keterampilan peserta didik yang harus dipenuhi atau dicapai dari suatu satuan pendidikan tertentu. Kompetensi lulusan pada setiap jenjang pendidikan dikembangkan untuk memenuhi tuntutan kebutuhan kompetensi abad 21, persaingan yang semakin 
mengglobal, dan kebutuhan lokal serta nasional Indonesia. Tabel 1 menyajikan kompetensi lulusan dimensi sikap pada tiap jenjang pendidikan.

\section{Tabel 1.}

Kompetensi lulusan dimensi sikap pada tiap jenjang pendidikan

\begin{tabular}{cl}
\hline Jenjang & \multicolumn{1}{c}{ Kualifikasi Kemampuan } \\
\hline SD/MI & $\begin{array}{l}\text { Memiliki perilaku yang mencerminkan sikap orang beriman, } \\
\text { berakhlak mulia, berilmu, percaya diri, dan bertanggung jawab dalam } \\
\text { berinteraksi secara efektif dengan lingkungan sosial dan alam di } \\
\text { lingkungan rumah, sekolah, dan tempat bermain }\end{array}$ \\
\hline SMP/MTs & $\begin{array}{l}\text { Memiliki perilaku yang mencerminkan sikap orang beriman, } \\
\text { berakhlak mulia, berilmu, percaya diri, dan bertanggung jawab dalam } \\
\text { berinteraksi secara efektif dengan lingkungan sosial dan alam dalam } \\
\text { jangkauan pergaulan dan keberadaannya }\end{array}$ \\
\hline Memiliki perilaku yang mencerminkan sikap orang beriman, \\
berakhlak mulia, berilmu, percaya diri, dan bertanggung jawab dalam \\
berinteraksi secara efektif dengan lingkungan sosial dan alam serta \\
dalam menempatkan diri sebagai cerminan bangsa dalam pergaulan \\
dunia
\end{tabular}

Sumber: Kemendikbud, 2013

Hal senada disampaikan oleh Kurniawan \& Fitriyani (2015: 10) bahwa pendidikan dalam konteks keilmuan, idealnya bergerak dalam tiga ranah: pemahaman-keilmuan, sikap, dan keterampilan. Akan tetapi, dalam pelaksanaannya, pendidikan di Indonesia lebih menekankan pada aspek pemahaman keilmuan. Hal ini bisa dilihat dari pandangan masyarakat bahwa nilai prestasi anak yang tinggi itu sangat penting. Sampai banyak anak yang ditekan oleh orang tuanya untuk memperoleh nilai yang bagus. Karena bagi mereka, nilai yang akan menentukan masa depan anaknya kelak. Padahal yang harus lebih dicermati adalah setiap anak mempunyai kemampuan dan passion yang berbeda. Di era globalisasi ini, diperlukan adanya pengembangan aspek sikap dan keterampilan pada anak.

Kompetensi inti pada kurikulum 2013 merupakan terjemahan atau operasionalisasi standar kompetensi lulusan dalam bentuk kualitas yang harus dimiliki peserta didik yang 
telah menyelesaikan pendidikan pada satuan pendidikan tertentu. Gambaran mengenai kompetensi utama yang dikelompokkan ke dalam aspek sikap, pengetahuan, dan keterampilan (afektif, kognitif, dan psikomotor) harus dipelajari peserta didik untuk suatu jenjang madrasah, kelas, dan mata pelajaran. Kompetensi inti harus menggambarkan kualitas yang seimbang antara pencapaian hard skills dan soft skills (Kurniasih \& Sani, 2014: 150). Tabel 2 menyajikan kompetensi inti 1 yang menggambarkan sikap spiritual dan kompetensi dasar.

\section{Tabel 2.}

Kompetensi Inti dan Kompetensi Dasar

\begin{tabular}{ll}
\hline \multicolumn{1}{c}{ Kompetensi Inti } & \multicolumn{2}{c}{ Kompetensi Dasar } \\
\hline Menghargai dan menghayati ajaran & Mengagumi keteraturan dan \\
agama yang dianutnya & kompleksitas ciptaan Tuhan tentang \\
& aspek fisik dan kimiawi, kehidupan \\
& dalam ekosistem, dan peranan manusia \\
& dalam lingkungan serta mewujudkannya \\
& dalam pengamalan ajaran agama yang \\
& dianutnya \\
\hline
\end{tabular}

Implementasi nilai-nilai pendidikan karakter pada pendidikan dasar dan menengah diperoleh dari semua mata pelajaran yang ada, adapun porsi terbesar didapat dari kelompok mata pelajaran agama, akhlak dan kewarganegaraan. Pendidikan sains juga menyumbang pendidikan nilai/karakter melalui bentuk pendidikan sikap ilmiah dan kerja ilmiah yang merupakan bagian metode ilmiah. Pendidikan nilai/karakter yang saat ini sedang digalakkan tidak berdiri sendiri sebagai mata pelajaran, tetapi harus dipadukan dengan materi pendukung kompetensi dasar yang sesuai (Salirawati, 2011).

Ilmu Pengetahuan Alam (IPA) berkaitan dengan cara mencari tahu tentang alam secara sistematis, sehingga IPA bukan hanya penguasaan kumpulan pengetahuan yang berupa fakta-fakta, konsep-konsep, atau prinsip-prinsip saja tetapi juga merupakan suatu proses penemuan. Pembelajaran IPA di MTs dikembangkan sebagai mata pelajaran integrative science atau IPA Terpadu bukan sebagai disiplin ilmu. Konsep keterpaduan ini ditunjukkan dalam 
Kompetensi Inti (KI) dan Kompetensi Dasar (KD) pembelajaran IPA yakni di dalam satu KD sudah memadukan konsep-konsep IPA dari bidang ilmu biologi, fisika, dan ilmu pengetahuan bumi dan antariksa (IPBA).

Pembelajaran IPA berorientasi pada kemampuan aplikatif, pengembangan kemampuan berpikir, kemampuan belajar, rasa ingin tahu, dan pengembangan sikap peduli dan tanggung jawab terhadap lingkungan sosial dan alam. IPA juga ditujukan untuk pengenalan lingkungan biologi dan alam sekitarnya, serta pengenalan berbagai keunggulan wilayah Nusantara. Melalui pembelajaran IPA, peserta didik dapat memperoleh pengalaman langsung, sehingga dapat menambah kekuatan untuk menerima, menyimpan, dan menerapkan konsep yang telah dipelajarinya. Dengan demikian, peserta didik terlatih untuk dapat menemukan sendiri berbagai konsep yang dipelajari secara menyeluruh (holistik), bermakna, autentik dan aktif (Kemendikbud, 2013: 172).

Spiritual berasal dari kata spirit yang dapat berarti semangat, moral, dan sukma/jiwa. Spiritual merupakan suatu hal yang berkaitan dengan kemampuan membangkitkan semangat atau jiwa, dan berhubungan dengan nilai-nilai religius. Teaching berarti mengajar, bukan hanya penyampaian ilmu pengetahuan dari guru ke peserta didik, tetapi juga bagaimana guru membimbing peserta didik untuk belajar, mengatur dan menciptakan kondisi yang ada di lingkungan peserta didik sehingga dapat melakukan kegiatan belajar. Secara sederhana, mengajar bertujuan untuk menyampaikan ilmu pengetahuan dan melatih pola pikir peserta didik. Jadi, spiritual teaching dapat dikatakan sebagai mengajar dan membimbing peserta didik dengan menanamkan nilai atau semangat religius yang diintegrasikan dalam konsep pengetahuan dan keterampilan sesuai dengan tujuan pembelajaran.

Perkembangan ilmu pengetahuan dan teknologi telah banyak membantu peningkatan kualitas dan kesejahteraan kehidupan umat manusia di dunia, tetapi harus disadari pula perlunya landasan etika serta dimensi spiritual dan moral dalam menyikapi iptek yang telah maju. Pendidikan seperti ini sering disebut oleh banyak pakar sebagai spiritual teaching. Spiritual 
teaching terdiri dari tiga unsur yaitu IQ (Intelligence Quotient), EQ (Emotional Quotient) dan SQ (Spiritual Quotient). Strategi spiritual teaching adalah rencana cermat melalui sebuah proses penyampaian dan penanaman pengetahuan atau keterampilan yang berkaitan dengan suatu mata pelajaran tertentu kepada peserta didik yang dilakukan oleh guru dalam kerangka pengabdian kepada Allah sebagai sang Maha Pemilik Ilmu dalam praktek model pembelajaran dengan pendidikan spiritual, dengan cara mencintai profesi dan peserta didiknya memberi penjelasan yang menghubungkan pembelajaran dengan ilmu keagamaan (Jumini \& Wahyudi, 2015: 4).

Jumini \& Wahyudi menambahkan bahwa ilmu agama dapat dijadikan penyeimbang dari ilmu sains, karena bila ilmu sains tidak diseimbangkan dengan ilmu agama maka akan menghasilkan kemajuan secara fisik tetapi kering dalam aspek spiritual. Hal ini juga dikarenakan ilmu agama berjalan beriringan dengan ilmu pengetahuan (sains), sebagai muslim tidak ada Islam tanpa pengetahuan, oleh karena itu Islam terdiri dari pengetahuan dan mengamalkan pengetahuan itu dalam bentuk tindakan. Kesimpulannya adalah bahwa selain kita mempelajari tentang materi dan ilmu pengetahuan maka kita dianjurkan untuk mengembalikan apa yang kita pelajari pada Sang Pencipta dan menarik benang merah ilmu pengetahuan dengan ilmu agama. Ilmu sains juga memuat ayat-ayat Ilahi yang tidak boleh dipungkiri, supaya nantinya akan terbentuk ilmuwan yang agamis dan agamawan yang intelek.

Apabila hal tersebut dibawa ke ranah pendidikan maka akan terbentuk suatu terobosan yang baru yaitu pengajaran yang mengkombinasikan antara ilmu agama (spiritual) dan ilmu pengetahuan (sains). Pengajaran menggunakan pendidikan spiritual di kelas diharapkan menghasilkan peserta didik yang berkarakter, sesuai dengan yang diharapkan oleh Undang-undang Sistem Pendidikan Nasional tahun 2003. Dan karakter yang tertanam dalam diri peserta didik jika menggunakan pendidikan spiritual adalah integritas (kejujuran), energik (semangat), wisdom (bijaksana), inspiration (banyak ide) dan spirit (kuat). 
Guru sebagai pendidik harus memiliki rasa mencintai terhadap profesi dan peserta didiknya, mendidik dilandasi dengan niat ikhlas beribadah kepada Allah SWT, mentransfer ilmu pengetahuan (transfer of knowledge) dan mampu menyampaikan nilai-nilai moral spiritual sehingga mampu mendidik sikap dan perilaku peserta didik menjadi lebih baik (transfer of value). Guru harus dapat menjadi teladan bagi peserta didik.

\section{B. Pembahasan}

\section{Implementasi Spiritual Teaching dalam Pembelajaran IPA di Madrasah}

Kurniasih \& Sani (2014: 65) menyatakan bahwa sikap spiritual terkait dengan pembentukan peserta didik yang beriman dan bertakwa. Kompetensi sikap adalah ekspresi dari nilai-nilai atau pandangan hidup yang dimiliki oleh peserta didik dan diwujudkan dalam perilaku. Dalam konteks penilaian sikap, indikator merupakan tanda-tanda yang dimunculkan oleh peserta didik, yang dapat diamati atau diobservasi oleh guru sebagai representasi dari sikap yang dinilai. Tabel 3 menyajikan daftar deskripsi indikator pada sikap spiritual.

\section{Tabel 3.}

Daftar Deskripsi Indikator Sikap Spiritual

\begin{tabular}{ll}
\hline Kompetensi \& Sikap spiritual & \multicolumn{1}{c}{ Indikator } \\
\hline - Berdoa sebelum dan sesudah menjalankan \\
sesuatu \\
- Menjalankan ibadah tepat waktu \\
- Memberi salam pada saat awal dan akhir \\
presentasi sesuai agama yang dianut \\
- Bersyukur atas nikmat dan karunia Allah \\
Yang Maha Esa \\
- Mensyukuri kemampuan manusia dalam \\
mengendalikan diri \\
- Mengucapkan syukur ketika berhasil \\
mengerjakan sesuatu \\
\hline
\end{tabular}




\begin{tabular}{ll}
\hline Kompetensi \& Sikap spiritual & \multicolumn{1}{c}{ Indikator } \\
\hline - & Berserah diri (tawakal) kepada Allah \\
& setelah berikhtiar atau melakukan usaha \\
- & Menjaga lingkungan hidup disekitar \\
& rumah tempat tinggal, madrasah, dan \\
& masyarakat \\
- & Memelihara hubungan baik dengan \\
& sesame umat ciptaan Allah Yang Maha \\
& Esa \\
- Bersyukur kepada Allah Yang Maha Esa & sebagai bangsa Indonesia \\
- & Menghormati orang lain menjalankan \\
& ibadah sesuai dengan agamanya
\end{tabular}

Sumber: Kurniasih \& Sani, 2014: 67

Menurut Mulyasa (2014: 101), pembelajaran menyenangkan, efektif dan bermakna dapat dirancang oleh setiap guru dengan prosedur seperti: 1) pemanasan dan apersepsi; 2) eksplorasi; 3) konsolidasi pembelajaran; 4) pembentukan sikap, kompetensi, dan karakter, dan 5) penilaian formatif. Konsolidasi merupakan kegiatan untuk mengaktifkan peserta didik dalam pembentukan kompetensi dan karakter, serta menghubungkannya dengan kehidupan peserta didik. Pembentukan sikap, kompetensi, dan karakter peserta didik dapat dilakukan dengan prosedur sebagai berikut:

1. Dorong peserta didik untuk menerapkan konsep, pengertian, kompetensi, dan karakter yang dipelajarinya dalam kehidupan sehari-hari

2. Praktekkan pembelajaran secara langsung, agar peserta didik dapat membangun sikap, kompetensi, dan karakter baru dalam kehidupan sehari-hari berdasarkan pengertian yang dipelajari

3. Gunakan metode yang paling tepat agar terjadi perubahan sikap, kompetensi, dan karakter peserta didik secara nyata.

Nilai yang sangat terkenal dan melekat yang mencerminkan akhlak/perilaku yang luar biasa tercermin pada Nabi Muhammad 
SAW, yaitu: (1) sidik, (2) amanah, (3) fatonah, (4) tabligh. Tentu dipahami bahwa empat nilai ini merupakan esensi, bukan seluruhnya. Karena Nabi Muhammad SAW juga terkenal dengan karakter kesabarannya, ketangguhannya, dan berbagai karakter lain. Sidik yang berarti benar, mencerminkan bahwa Rasulullah berkomitmen pada kebenaran, selalu berkata dan berbuat benar, dan berjuang untuk menegakkan kebenaran. Amanah yang berarti terpercaya, mencerminkan bahwa apa yang dikatakan dan apa yang dilakukan Rasulullah dapat dipercaya oleh siapa pun, baik oleh kaum muslim maupun non muslim. Fatonah berarti cerdas/ pandai, arif, luas wawasan, terampil, dan profesional. Artinya, perilaku Rasulullah dapat dipertanggungjawabkan kehandalannya dalam memecahkan masalah. Tabligh yang bermakna komunikatif mencerminkan bahwa siapa pun yang menjadi lawan bicara Rasulullah, maka orang tersebut akan mudah memahami apa yang dibicarakan/dimaksud oleh Rasulullah SAW (Kesuma, et al., 2012: 11).

Pengalaman belajar anak dalam setting pendidikan karakter dilakukan dalam tiga tempat, yaitu kelas, madrasah, dan rumah. Hal ini mengimplikasikan bahwa guru harus merancang dalam silabus dan RPP mengenai pengalaman apa yang harus dilalui oleh anak dalam upaya penguatan suatu nilai di madrasah dan di rumah. Jadi yang harus dipikirkan oleh guru bukan lingkup kelas semata, tetapi juga lingkup madrasah dan rumah, bahkan masyarakat di suatu daerah.

Desain pembelajaran yang dikembangkan oleh guru kemudian menjadi layanan proses pembelajaran bagi peserta didik. Layanan proses pembelajaran dalam pendidikan karakter harus memenuhi tiga kunci berikut: dasar pendidikan adalah kasih sayang, syarat teknis adalah saling percaya, dan syarat mutlak adalah kewibawaan. Proses pembelajaran yang difasilitasi oleh guru merupakan bentuk/wujud kasih sayang guru terhadap anak, bukan dipersepsi dan diasumsikan sebagai pelaksanaan tugas/ kerja sebagai PNS/guru honorer di suatu madrasah. Syarat teknis adalah saling percaya maksudnya bahwa interaksi pembelajaran dalam pendidikan karakter yang dibangun oleh guru mensyaratkan adanya saling percaya antara guru dengan peserta didik, peserta 
didik dengan peserta didik, dan lingkungan pendidikan dengan peserta didik. Hal ini menunjukkan bahwa guru memiliki peran yang besar untuk memberikan keteladanan pada peserta didik yang memiliki potensi yang harus difasilitasi oleh guru dan lingkungannya. Syarat mutlak adalah kewibawaan maksudnya adalah proses pendidikan karakter tidak akan terwujud (tidak menghasilkan kepemilikan karakter oleh anak) manakala guru diasumsikan tidak berwibawa di mata peserta didik. Kewibawaan adalah suatu kondisi di mana anak mengasumsikan bahwa guru memiliki kelayakan sebagai seorang guru. Kewibawaan merupakan suatu kondisi yang lahir secara alamiah berdasarkan interaksi anak dengan lingkungannya, bukan sesuatu yang dibuat-buat oleh guru, semisal dengan memarahi anak yang tidak menghormati guru tersebut atau dengan menegakkan aturan yang sangat keras/ ketat sebagaimana pengkondisian di instansi militer (Kesuma, et al., 2012: 112).

Pendidikan karakter religius dalam IPA menurut Susilawati (2012: 113) bukan merupakan mata pelajaran yang berdiri sendiri atau merupakan nilai yang diajarkan, tetapi lebih kepada upaya penanaman nilai-nilai yang dilakukan secara terintegrasi dalam mata pelajaran IPA. Aspek yang harus diperhatikan dalam menanamkan karakter religius dalam IPA adalah mengaitkan nilainilai tersebut secara eksplisit dalam perencanaan pembelajaran, pelaksanaan pembelajaran dan penilaian pembelajaran yang disesuaikan dengan karakteristik mata pelajaran IPA. Pengintegrasian karakter religius pada mata pelajaran IPA disesuaikan dengan hakikat IPA yang menekankan pada aspek IPA sebagai produk, IPA sebagai proses, dan IPA sebagai sikap.

Nilai-nilai yang dapat ditanamkan melalui proses pembiasaan pada mata pelajaran IPA di madrasah tidak hanya sebatas nilai religius dalam arti sempit tetapi juga nilai-nilai religius dalam arti luas seperti jujur, toleransi, disiplin, kerja keras, kreatif, mandiri, demokratis, rasa ingin tahu, semangat kebangsaan, cinta tanah air, menghargai prestasi, bersahabat/komunikatif, cinta damai, gemar membaca, peduli lingkungan, peduli sosial, dan tanggung jawab. Hal ini sejalan dengan aspek sikap ilmiah dalam IPA yang dapat dikembangkan pada peserta didik madrasah, 
yaitu: 1) sikap ingin tahu, 2) sikap ingin mendapatkan sesuatu yang baru, 3) sikap kerja sama, 4) sikap tidak putus asa, 5) sikap tidak berprasangka, 6) sikap mawas diri, 7) sikap bertanggung jawab, 8) sikap berpikir bebas, dan 9) sikap kedisiplinan diri.

Sikap religius menjadi komponen penting dalam seluruh aspek kehidupan manusia. Di mana agama akan membawa arah hidup menjadi lebih baik. Agama akan mewarnai karakter shalih seseorang. Agama akan menuntun hati menjadi ikhlas berbuat baik (kasmadi, 2013: 109).

Spiritual teaching dapat diterapkan dalam pembelajaran IPA di madrasah diantaranya melalui beberapa cara sebagai berikut:

\section{a. Pembelajaran Reflektif}

Spiritual teaching berkaitan erat dengan pendidikan karakter. Salah satu cara menerapkan spiritual teaching dapat melalui pembelajaran reflektif. Pembelajaran reflektif adalah pendidikan karakter yang terintegrasi/melekat pada semua mata pelajaran/bidang studi di semua jenjang dan jenis pendidikan. Proses pembelajaran dilakukan oleh semua guru mata pelajaran seperti guru Matematika, IPA, IPS, Bahasa Indonesia, dan mata pelajaran lainnya. Proses pembelajaran reflektif dilakukan melalui pengaitan materi-materi yang dibahas dalam pembelajaran dengan makna di belakang materi tersebut. Dengan kata lain, dalam proses pembelajaran guru menjawab pertanyaan mengapa suatu materi itu ada dan dibutuhkan dalam kehidupan (Kesuma, et al., 2012: 115).

Contoh pembelajaran refleksi spiritual yang dapat dilakukan oleh guru IPA pada materi tentang darah sebagai berikut:

Setelah peserta didik mengelaborasi materi tentang darah (komponen, fungsi, dan karakteristik lainnya) kemudian diakhir sesi pembelajaran guru bertanya kepada anak, "Anakanak menurut kamu siapakah sebenarnya yang mengatur darah di dalam diri manusia dan makhluk hidup lainnya yang memiliki darah? Kebanyakan anak dengan spontan menjawab "Allah..." Namun demikian beberapa anak lain tidak menjawab. Kondisi ini dipahami oleh guru sebagai suatu kondisi yang memerlukan penguatan karakter anak, yaitu karakter tentang berserah diri 
terhadap Allah SWT. Kemudian guru meminta pada anak-anak untuk menjelaskan lebih lanjut, "Coba bagaimana kita mengetahui bahwa Allah lah yang mengatur darah yang berada di dalam tubuh kita?”.

Pada saat itu belum ada anak yang mampu menjawab pertanyaan guru. Kemudian guru memberikan pertanyaan pancingan lagi supaya anak-anak dapat merefleksi mengenai materi tentang "darah" ini menjadi bagian dari penguatan karakter bagi anak. "Nah anak-anak, siapa sebenarnya yang menciptakan manusia dan alam semesta?" Anak-anak menjawab dengan spontan "Allah..." lalu guru kemudian bertanya lagi,"jika Allah yang menciptakan semua makhluknya, apakah Allah juga yang mengatur darah di dalam diri manusia?” kemudian mereka menjawab secara spontan "ya...".

Pada saat itu guru memahami bahwa suatu hal yang sulit untuk membuktikan bagaimana keterlibatan Allah SWT dalam pengaturan darah manusia. Kemudian dia menjelaskan tentang proses penciptaan manusia mulai dari pertemuan sperma dengan ovum. Dalam penjelasannya guru mengutip Qur'an Surat Al Alaq ayat 2 yang artinya "Dia yang menciptakan manusia dari segumpal darah". Berdasarkan refleksi tersebut, kemudian guru meminta anak-anak di kelas untuk mencari pengetahuan atau wawancara kepada keluarga terdekat tentang "kaitan antara darah dengan kesehatan dan kondisi darah dengan psikologi seseorang”.

Muspiroh (2013: 495) mengungkapkan, pada materi tata surya, guru dapat menyisipkan nilai keimanan. Tata surya terdiri dari planet-planet, bintang, satelit, asteroid, dan meteorit. Matahari adalah pusat dari tata surya. Semuanya berjalan sesuai garis edarnya. Berotasi dan berevolusi sesuai dengan lintasan dan waktu yang berbeda-beda. Kesemuanya itu telah diatur oleh Allah SWT. Apabila tidak ada yang mengatur maka planet-planet itu akan bertabrakan satu sama lain. Hal ini sesuai dengan Qur'an Surat ArRa'd ayat 2 yang artinya "Allah-lah yang meninggikan langit tanpa tiang (sebagaimana) yang kamu lihat, kemudian dia bersemayam di atas 'Arasy, dan menundukkan matahari dan bulan, masing-masing beredar hingga waktu yang ditentukan. Allah mengatur urusan 
(makhluk-Nya), menjelaskan tanda-tanda (kebesaran-Nya), supaya kamu meyakini pertemuan (mu) dengan Tuhanmu".

Winarti (2015: 58) mengembangkan modul pembelajaran Fisika diintegrasikan dengan nilai spiritual. Selain materi yang terintegrasi dengan Islam (ayat-ayat Al Quran), modul juga dilengkapi dengan refleksi. Refleksi ini bertujuan untuk memberi renungan kepada peserta didik tentang kebesaran Allah untuk menanamkan nilai-nilai keislaman. Contoh refleksi sebagai berikut: 1) Saat kita berjalan di bawah terik matahari, ingatlah bahwa panas matahari merupakan salah satu nikmat yang diberikan Allah yang dapat kita manfaatkan; 2) Pernahkah kalian membayangkan derajat panasnya neraka? Bagaimana jika kalian ada di sana?; 3) Tuhan menciptakan hukum alam agar kita berpikir dan menyadari akan kebesaran-Nya bahwa setiap peristiwa pasti ada penyebab dan penjelasannya serta semua ciptaan Tuhan dapat dijelaskan secara ilmiah dan masuk akal.

Pembelajaran reflektif dapat dievaluasi. Evaluasi pembelajaran reflektif adalah evaluasi yang ditujukan untuk melihat sejauh mana berbagai karakter dan nilai yang dikembangkan dapat dimiliki oleh anak. Evaluasi ini dilakukan melalui observasi terhadap perilaku anak. Observasi dilakukan melalui lisan, perbuatan, raut muka, gerak badan, dan berbagai hal lainnya. Evaluasi yang tepat dilakukan adalah observasi terhadap pemikiran dan sikap anak.

\section{b. Pembelajaran Kontekstual (CTL)}

Integrasi pendidikan karakter di dalam proses pembelajaran dilaksanakan mulai dari tahap perencanaan, pelaksanaan, hingga evaluasi pembelajaran. Pada tahap perencanaan dilakukan analisis Kompetensi Dasar, pengembangan silabus, penyusunan RPP, dan penyiapan bahan ajar. Kegiatan pembelajaran dari tahapan pendahuluan, inti, dan penutup, dipilih dan dilaksanakan agar peserta didik mempraktekkan nilai-nilai karakter yang ditargetkan. Prinsip contextual teaching and learning disarankan diaplikasikan pada semua tahapan pembelajaran karena prinsip pembelajaran tersebut sekaligus dapat memfasilitasi terinternalisasikannya nilai-nilai. Selain itu, perilaku guru sepanjang proses pembelajaran harus merupakan model pelaksanaan nilai-nilai bagi peserta didik. 
Tugas-tugas penguatan terutama pengayaan diberikan untuk memfasilitasi peserta didik belajar lebih lanjut tentang kompetensi yang sudah dipelajari dan internalisasi nilai lebih lanjut. Tugastugas tersebut antara lain dapat berupa PR yang dikerjakan secara individu atau kelompok baik yang dapat diselesaikan dalam waktu singkat ataupun panjang. Tugas tersebut dapat meningkatkan penguasaan yang ditargetkan, juga menanamkan nilai-nilai (Khusniati, 2012: 206).

Pembelajaran kontekstual mengkaitkan materi pelajaran dengan dunia nyata. Pembelajaran ini dapat meningkatkan motivasi peserta didik di madrasah karena dapat menghubungkan pengetahuan peserta didik yang diperoleh di madrasah dengan kehidupan sehari-hari. Pembelajaran ini dapat menjadi lebih bermakna dan pemahaman konsep peserta didik lebih baik.

Pendekatan kontekstual dalam pembelajaran IPA misalnya pada materi pemisahan campuran, peserta didik melakukan praktikum pemurnian garam. Pemurnian garam $(\mathrm{NaCl})$ dipilih karena garam sendiri merupakan senyawa yang sering digunakan dalam kehidupan sehari-hari. Pemilihan topik yang erat kaitannya dengan kehidupan peserta didik, tentunya akan membuat peserta didik antusias dengan pembelajaran tersebut. Banyak karakter yang dapat ditumbuhkan dari praktikum pemurnian garam tersebut. Materi yang dekat dengan kehidupan peserta didik tentunya akan menumbuhkan rasa ingin tahu dan cinta ilmu. Kegiatan praktikum yang dilakukan secara berkelompok juga mampu menanamkan karakter tanggung jawab karena setiap peserta didik harus melaksanakan tugasnya masing-masing, menghargai pendapat orang lain, kreatif, disiplin dengan tugasnya, serta mampu menghargai perbedaan pendapat.

Kegiatan refleksi setelah praktikum juga mampu menumbuhkan berbagai karakter, diantaranya yaitu dapat menumbuhkan kemampuan berfikir logis dan kritis, mengetahui kelebihan dan kekurangan diri sendiri, dan menghargai pendapat orang lain. Contoh pembelajaran tersebut menunjukkan bahwa pembelajaran IPA dapat digunakan untuk menanamkan pendidikan karakter bagi peserta didik (Khusniati, 2012: 209). Nilai spiritual dapat ditanamkan pada praktikum pemurnian 
garam dengan cara mensyukuri karunia yang diberikan Allah SWT berupa lautan sebagai salah satu sumber pembuatan garam. Peserta didik juga harus dapat menjaga lingkungan terutama lautan sebagai ciptaan Allah SWT sebagai wujud pengamalan agama Islam.

\section{c. Spiritual Educational Games (SEG)}

Suyadi (2015: 16) menggagas tentang Spiritual Educational Games (SEG) untuk menyiapkan generasi bangsa yang religius sejak dini. SEG adalah konsep permainan edukatif untuk pengembangan kecerdasan spiritual anak yang dikembangkan dari tiga komponen, yakni kecerdasan majemuk (multiple intelligence) dari Howard Gardner, Play and Learn dari Montessori, dan SQ for Kids dari Jalaludin Rakhmat. Kecerdasan majemuk (multiple intelligence) adalah kecerdasan ganda, yang terdiri dari Sembilan kecerdasan, yakni kecerdasan lingusitik, kinestetik, logika matematis, visual, musical, interpersonal, intrapersonal, naturalistik, dan eksistensial.

Play and Learn adalah gagasan Montessori tentang bermain dan belajar. Menurutnya, tidak semua permainan mengandung unsur edukasi atau pendidikan. Oleh karena itu, diperlukan kategori permainan yang sarat terhadap nilainilai edukatif. SQ for Kids adalah gagasan Jalaludin Rakhmat untuk mengembangkan kecerdasan spiritual anak. Gagasan ini semacam kiat-kiat tertentu. Ketiga teori tersebut disinergikan dan dikombinasikan untuk membuat sebuah model baru berupa permainan edukatif spiritual.

Suyadi mengelompokkan spiritual educational games (SEG) menjadi tiga jenis, yaitu:

1. SEG berbasis alat atau benda (boneka spiritual, menara ajaib, puzzle transcendental).

2. SEG berbasis aktivitas (panji-panji spiritual, drama, peran dan pantomim).

3. SEG berbasis multimedia interaktif (teknologi digital), misalnya puzzle interaktif, pesawat imajinatif, sutradara maya. 
Penerapan Spiritual Educational Games dalam pembelajaran IPA tentu saja disesuaikan dengan tingkat perkembangan peserta didik dan disesuaikan dengan materi pembelajaran. Walaupun Suyadi mengatakan bahwa SEG lebih tepat digunakan pada lembaga PAUD maupun Raudlatul Athfal/TK, namun permainan ini tidak menutup kemungkinan untuk diterapkan pada peserta didik di madrasah.

Game sebagai suatu hal yang dianggap menyenangkan dapat digunakan untuk memuat konten-konten edukasi yang dapat membantu dalam menyampaikan nilai-nilai positif dalam membangun kecerdasan manusia secara utuh. Karena game dapat melatih kemampuan otak secara aktif, merangsang otak dalam membuat keputusan, lebih mempunyai tantangan. Macam-macam game antara lain: aksi, aksi petualangan, simulasi, konstruksi dan manajemen, role playing games, strategi, balapan, olah raga, puzzle, dan permainan kata. Game edukasi dapat meningkatkan pemahaman peserta didik dalam belajar IPA (Intan Sari, et al., 2013).

\section{d. Pembelajaran Outdoor}

Pembelajaran IPA diharapkan dapat menjadi wahana bagi peserta didik untuk mempelajari diri sendiri dan alam sekitar, serta prospek pengembangan lebih lanjut dalam menerapkannya di dalam kehidupan sehari-hari. Proses pembelajarannya menekankan pada pemberian pengalaman secara langsung untuk mengembangkan kompetensi dalam menjelajahi dan memahami alam sekitar secara ilmiah. Pembelajaran IPA diarahkan untuk inkuiri dan berbuat sehingga dapat membantu peserta didik untuk memperoleh pemahaman yang lebih mendalam tentang alam sekitar (Kemendikbud, 2013: 212).

Salah satu proses pembelajaran yang dapat meningkatkan sikap spiritual peserta didik adalah melalui pembelajaran IPA yang dilaksanakan di luar kelas (outdoor class). Dalam praktiknya, proses pembelajaran dapat dilakukan di luar kelas (masih dalam lingkungan madrasah) maupun di luar lingkungan madrasah, misalnya di kebun binatang, area persawahan, taman pintar, atau museum. 
Menurut Hartono (2011: 13), aktivitas pembelajaran alam menjadi pilihan yang tepat untuk pembelajaran integrasi sains dan agama. Jika sains menjadikan alam semesta sebagai obyek keilmuannya, agama memerintah manusia untuk berpikir mengenai alam ciptaan Allah. Allah juga telah menggambarkan alam semesta dalam Al Qur'an melalui ayat-ayat kauniyah.

Guru harus dapat membangkitkan motivasi peserta didik terhadap hal yang dipelajari di luar kelas, serta cara menggerakkan tingkah laku, mengarahkan, dan memperkuat tingkah laku peserta didik di luar kelas. Pembelajaran outdoor dapat meningkatkan kecerdasan intelektual, emosional dan spiritual peserta didik (Asiah \& Mintohari, 2014). Peserta didik dapat mengamati secara langsung fenomena yang ada di lingkungan alam sekitar, mengumpulkan data-data yang ada, dan dapat dijadikan laporan hasil pengamatan, yang dapat didiskusikan dalam kelas maupun dipresentasikan.

Pembelajaran outdoor dapat diterapkan misalnya pada materi tentang ekosistem. Untuk memberikan motivasi dan nilai spiritual pada peserta didik, guru dapat menyampaikan Qur'an Surat Al An'am ayat 99 yang artinya,"Dan Dialah yang menurunkan air hujan dari langit, lalu Kami tumbuhkan dengan air itu segala macam tumbuh-tumbuhan itu tanaman yang menghijau. Kami keluarkan dari tanaman yang menghijau itu butir yang banyak; dan dari mayang korma mengurai tangkai-tangkai yang menjulai, dan kebun-kebun anggur, dan (Kami keluarkan pula) zaitun dan delima yang serupa dan yang tidak serupa. Perhatikanlah buahnya di waktu pohonnya berbuah dan (perhatikan pulalah) kematangannya. Sesungguhnya pada yang demikian itu ada tanda-tanda (kekuasaan Allah) bagi orang-orang yang beriman". Maksud ayat ini adalah kita dianjurkan untuk mengamati tanaman mulai dari tumbuh sampai berbuah, sebagai tanda kekuasaan Allah. Mengamati tanaman berarti juga mengamati lingkungan sekitar kita yang meliputi komponen biotik dan abiotik.

Peserta didik melakukan kegiatan pengamatan lingkungan madrasah, di halaman madrasah, kebun, parit, kolam, sawah, dan mencatat data atau hasil pengamatan. Dengan kegiatan mengamati, dapat meningkatkan rasa ingin tahu peserta didik dan 
dapat mensyukuri karunia Allah berupa lingkungan yang terdiri dari beberapa ekosistem. Peserta didik juga harus dapat menjaga lingkungan ekosistem dengan baik. Pada saat pengamatan, peserta didik dapat menjaga sikap peduli lingkungan dan tanggung jawab dengan tidak memetik tanaman apalagi merusak tanaman untuk tujuan yang tidak jelas.

Pengintegrasian pendidikan karakter dalam mata pelajaran IPA menurut Susilawati (2012: 109) harus dieksplisitkan, sehingga guru IPA dapat melakukan hal-hal berikut:

1. Melakukan analisis Standar Kompetensi dan Kompetensi Dasar (sekarang KI-KD) serta pemetaan materi pembelajaran.

2. Melakukan analisis tokoh di balik sebuah konsep IPA untuk menemukan nilai-nilai kehidupan apa yang diterapkannya sehingga menjadi orang sukses.

3. Memposisikan IPA sebagai mata pelajaran yang mengkaji, mempelajari, dan membuktikan kebesaran-kebesaran Allah SWT dan ketetapan-ketetapan-Nya untuk alam semesta.

4. Merumuskan indikator pencapaian Kompetensi Dasar dengan menyertakan kualitas-kualitas moral dan spiritual. Sebagai contoh pada rumusan berikut:

a. Peserta didik dapat menjelaskan konsep ... dengan tepat dan percaya diri.

b. Peserta didik dapat menerapkan konsep ... secara mandiri dan jujur.

c. Peserta didik dapat menyebutkan aspek kebesaran Allah SWT dalam konsep ....

5. Mengembangkan proses pembelajaran aktif untuk internalisasi nilai.

Internalisasi nilai-nilai spiritual dalam pembelajaran IPA dapat meningkatkan motivasi belajar peserta didik di madrasah. Hal ini senada dengan Hartono (2011: 153) bahwa integrasi sains dan agama dalam pembelajaran telah menawarkan konsep baru mengenai kajian agama atau sains. Materi integrasi menjadikan proses pembelajaran tidak monoton. Monoton menurut agama 
artinya tidak diterangkan menurut wahyu saja. Begitu pula dengan sains tidak diterangkan menurut teori-teori Barat yang ada sampai saat ini. Kondisi ini mampu membangkitkan semangat belajar bagi peserta didik. Jika semangat telah terbangun, maka kesediaan untuk belajar juga meningkat. Jika belajar telah menjadi bagian yang tetap dari kehidupan peserta didik, maka akan membuka peluang untuk memahami sesuatu dengan cepat, mudah, dan baik.

Allah SWT memberikan anugerah kepada manusia berupa tiga nikmat potensial, yaitu kemampuan pendengaran, kemampuan pengamatan, dan kemampuan hati nurani. Setiap sesuatu yang didengar akan mengisi, menambah, dan merevisi halaman pengetahuan, serta membuka ruang aktualisasi diri dalam konteks hubungan sosial maupun hubungannya kepada Tuhan. Makna melihat tidak hanya sekedar menatap dengan mata, tetapi juga kemampuan mengamati dan menganalisa untuk mengembangkan konsepsi ilmiah maupun nilai-nilai agama sebagai kebutuhan hidup. Hati nurani, bukan untuk menyuarakan keluhan batiniyah, menyalahkan, membandingkan, tetapi memiliki daya mengelaborasi dan mengeksplorasi dengan membuat evaluasi dan uji kebenaran dalam menjawab setiap persoalan hidup. Orang yang mampu mengembangkan ketiga komponen potensial tadi, akan menguasai ilmu pengetahuan dan teknologi yang pada gilirannya dapat membangun peradaban maju. Seorang yang cerdas dalam mengelola kekayaan pikirannya, maka ia akan cerdas pula menggabungkan pola-pola berpikir dalam beragam aspek. Ia mampu mengembangkan aspek spiritual, membangun kepercayaan diri, sikap sosial tinggi, menciptakan spirit kekeluargaan, betanggungjawab, berinteraksi dengan nyaman, dan aspek mendidik diri (Kasmadi, 2013: 62).

Kasmadi menambahkan bahwa pencerah kehidupan adalah membangun kemauan dan meningkatkan keilmuan. Sebab dengan ilmu, seseorang akan mampu keluar dari alam kegelapan menuju cahaya. Lebih jauh lagi, melalui ilmu seseorang dapat memaknai hidup dan pandai bersyukur. Firman Allah SWT dalam Al Qur'an Surat An Nahl ayat 78 yang artinya, "Dan Allah mengeluarkan kamu dari perut ibumu dalam keadaan 
tidak mengetahui sesuatupun. Dan memberimu pendengaran, penglihatan, dan hati nurani, agar kamu bersyukur".

Melalui pengembangan Kurikulum 2013 yang berbasis karakter dan berbasis kompetensi, kita berharap bangsa ini menjadi bangsa yang bermartabat, dan masyarakatnya memiliki nilai tambah (added value), dan nilai jual yang bisa ditawarkan kepada orang lain dan bangsa lain di dunia, sehingga kita bisa bersaing, bersanding, bahkan bertanding dengan bangsa-bangsa lain dalam percaturan global. Hal ini dimungkinkan, kalau implementasi Kurikulum 2013 betul-betul dapat menghasilkan insan yang produktif, kreatif, inovatif, dan berkarakter (Mulyasa, 2014: 7). Guru harus dapat mengimplementasikan Kurikulum 2013 dengan baik agar tujuan dapat tercapai.

\section{Simpulan}

Guru mata pelajaran IPA di madrasah harus dapat menanamkan nilai-nilai spiritual pada pembelajaran dan dapat menjadi teladan bagi peserta didik. Spiritual teaching pada pembelajaran IPA di madrasah dapat diimplementasikan melalui beberapa cara, diantaranya melalui: 1) Pembelajaran Reflektif, 2) Pembelajaran Kontesktual (CTL), 3) Spritual Educational Game (SEG), dan 4) Pembelajaran Outdoor. Guru dapat memilih pembelajaran yang akan diterapkan disesuaikan dengan materi yang disampaikan. Apabila guru menerapkan spiritual teaching dalam pembelajaran IPA di madrasah, diharapkan terwujud peserta didik yang cerdas secara komprehensif, cerdas intelektual, cerdas spiritual, dan cerdas sosial/emosional. 


\section{DAFTAR PUSTAKA}

Aisah, Siti \& Mintohari. 2014. Penerapan Metode Outdoor Activity dalam Pembelajaran IPA untuk Meningkatkan Hasil Belajar Siswa Sekolah Dasar. Jurnal Penelitian Pendidikan Guru Sekolah Dasar Vol 2, No 3, (2014).

Hartono. 2011. Pendidikan Integratif. Purwokerto: Penerbit STAIN Press.

Intan Sari, Putri., Eka Purnama, Bambang., \& Uly Wardati, Indah. 2013. Game Edukasi Mata Pelajaran Ilmu Pengetahuan Alam (IPA) dan Ilmu Pengetahuan Sosial (IPS) pada Sekolah Dasar Negeri Sooka 1 Punung Kabupaten Pacitan. IJCSS-Indonesian Jurnal on Computer Science-Speed-FTI UNSA-ijcss.unsa.ac.id.ISSN: 1979-9330 (Print)-20880154 (Online)

Jumini, Sri \& Wahyudi. 2015. Konsep Vektor dan Nilai-nilai Pendidikan Spiritual didalamnya (Telaah Buku: "Analisis Vektor” Kajian Teori Pendekatan Al-Qur'an Karya Ari Kusumastuti). Jurnal PPKM 1 (2015) 1 - 10. ISSN: 2354869X.

Kasmadi. 2013. Membangun Soft Skills Anak-anak Hebat Pembangunan Karakter \& Kreativitas Anak. Bandung: Alfabeta.

Kesuma, Dharma., Triatna, Cepi., \& Permana, Johar. 2012. Pendidikan Karakter Kajian Teori dan Praktik di Sekolah. Bandung: PT. Remaja Rosdakarya.

Kemendikbud. 2013. Materi Pelatihan Guru Implementasi Kurikulum 2013 SMP/MTs Ilmu Pengetahuan Alam. Badan Pengembangan Sumber Daya Manusia Pendidikan dan Kebudayaan dan Penjaminan Mutu Pendidikan.

Khusniati, M. 2012. Pendidikan Karakter Melalui Pembelajaran IPA. Jurnal Pendidikan IPA Indonesia (JPII) 1 (2) (2012) 204 - 210. Diakses dari http://journal.unnes.ac.id/index. php/jpii. 
Kurniasih, Imas \& Sani, Berlin. 2014. Implementasi Kurikulum 2013 Konsep \& Penerapan. Surabaya: Kata Pena.

Kurniawan, Heru \& Fitriyani, Feny Nida. 2015. Pendidikan Global-Religius di Madrasah: Mewujudkan Generasi yang Berilmu Pengetahuan Global dan Berkarakter Islam. AlIttihad Volume 2, November 2015. ISSN: 2407-2095.

Mulyasa. 2014. Pengembangan dan Implementasi Kurikulum 2013. Bandung: PT Remaja Rosdakarya.

Muspiroh, Novianti. 2013. Integrasi Nilai Islam dalam Pembelajaran IPA (Perspektif Pendidikan Islam). Jurnal Pendidikan Islam Vol XXVIII No 3 2013/1435.

Salirawati, Das. 2011. Pendidikan Karakter Terintegrasi dalam Mata Pelajaran. Makalah. Disampaikan pada Workshop Peningkatan Mutu Pembelajaran di SD pada hari Rabu, 16 Februari 2011, di SD Negeri 3 Pengasih, Kulon Progo.

Susilawati. 2012. Karakter Religius Pembelajaran IPA. Jurnal Pendidikan Islam Vol. XVII No. 1 2012/1433.

Suyadi. 2015. Cerdas dengan Spiritual Educational Games. Jakarta: Saufa.

Winarti. 2015. Pengembangan Perangkat Pembelajaran Fisika Bermuatan Integrasi Islam-Sains untuk Menanamkan Nilai-nilai Spiritual Siswa Madrasah Aliyah. JPFK, Vol. 1 No. 2, September 2015, hal 54-60. 